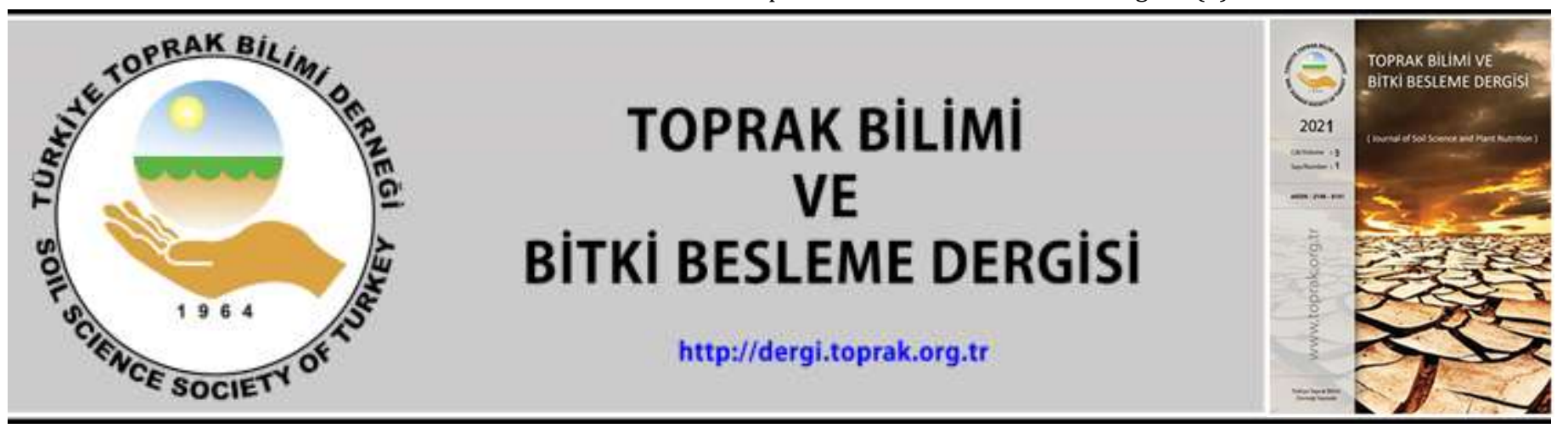

\title{
Farklı kaynaklardan elde edilen organik materyalin kumlu tın bünyeli toprağın bazı özellikleri üzerine etkileri
}

\author{
Remzi İlay*, @Meltem Aktaş, @Nuri Burak Aslantekin, ๑Hasan Özcan
}

\author{
${ }^{1}$ Çanakkale Onsekiz Mart Üniversitesi Ziraat Fakültesi, Toprak Bilimi ve Bitki Besleme Bölümü, Çanakkale
}

\begin{abstract}
Özet
Organik materyaller toprakların sürdürülebilir olmasında önemli yer tutmaktadır. Toprağa organik madde kaynağı olarak ilave edilen birçok materyal, karbonun toprakta tutulması ve depolanması gibi doğrudan olumlu etkisinin yanında toprağın fiziksel, kimyasal ve biyolojik özelliklerini iyileştirici etkiye sahiptir. Organik toprak düzenleyici olarak en çok tercih edilen materyallerden biri olan leonardit; organik maddelerin kömürleșme süreçlerinden etkilenmeyerek oksitlenmesiyle olușan ve humik asitçe zengin doğal bir materyaldir. Humik asitçe zengin olması ve yüksek karbon içeriği, toprak ıslahı ve bitkisel üretim açısından önemli bir yer tutmaktadır. Bu çalışma, Kayseri-Develi (DL) ve Çanakkale-Yenice (YL) olmak üzere iki farklı bölgeden temin edilen leonarditin kumlu tın (SL) bünyeye sahip toprağın bazı özeliklerine kısa süreli etkilerini tespit etmek amacıyla yapılmıştır. Bu amaçla leonardit çeşitleri beş farklı dozda (\%4, \%8, \%12, \%16, \%20) kumlu tın (SL) bünyeye sahip toprak ile karıştırılarak üç ay inkübe edilmiştir. İnkübasyon süresi sonunda tüm uygulamalar için toprağın organik maddesi $(\mathrm{OM})$, toprak reaksiyonu (pH), elektriksel iletkenliği (EC), kireç içeriği $\left(\mathrm{CaCO}_{3}\right)$, kuru hacim ağırlığı $(\mathrm{dB})$, hidrolik iletkenliği (Ks), agregat stabilitesi (AS) ve boșluk hacmi (P) gibi özellikleri belirlenerek leonarditlerin etkisi araștırılmıștır. Uygulanan dozlara bakılmaksızın her iki leonardit uygulamasıyla kontrole göre EC (\%236), OM (\%213), AS (\%50), P (\%11) artarken, dB (\%10) azalmıștır ( $\mathrm{p} \leq 0.05)$. Buna rağmen diğer parametrelerdeki değişimler $\left(\mathrm{pH}, \mathrm{CaCO}_{3}, \mathrm{Ks}\right)$ istatistiksel olarak önemsiz bulunmuştur $(\mathrm{p} \geq 0.05)$. Genel olarak leonardit çeşidinin incelenen parametreler üzerine etkisinin önemsiz $(\mathrm{p} \geq 0.05)$ olduğu tespit edilmiştir.
\end{abstract}

Anahtar Kelimeler: Leonardit, toprak, agregat stabilitesi, organik madde, porozite

\section{The effects of organic materials obtained from different sources on some properties of sandy loam soil}

\begin{abstract}
The addition of organic materials to the soil is important due to the sustainability of soil resources and their positive contribution to soil properties. Many materials that are added to the soil as a source of organic matter have direct positive effects, such as storing and storing carbon in the soil, as well as improving the physical, chemical and biological properties of the soil. Leonardite is one of the most preferred organic soil conditioner, which is rich in humic acid and formed by oxidizing organic materials without being affected by carbonization processes. Due to having high humic acid and carbon content, it has an important place in terms of soil improvement and vegetative production. This study was carried out to determine the short-term effects of leonardite obtained from two different sources ((Kayseri-Develi (DL) and Çanakkale-Yenice (YL)) on some properties of the soil with sandy loam (SL). For this purpose, each leonardite type was mixed with sandy loam (SL) soil at the rate of five different doses (4\%, 8\%, 12\%, 16\%, 20\%) and they were incubated for three months. Soil organic matter (OM), soil reaction ( $\mathrm{pH})$, electrical conductivity (EC), lime content $\left(\mathrm{CaCO}_{3}\right)$, bulk density $(\mathrm{dB})$, saturated hydraulic conductivity (Ks), aggregate stability (AS) and total porosity (P) of mixtures were determined at the end of the incubation period to investigate the effects of leonardite. Leonardite applications increased EC (236\%), OM (213\%), AS (50\%) and P (11\%) while decreased $\mathrm{dB}(10 \%)$ compared to control $(\mathrm{p} \leq 0.05)$. However, changes in other parameters $\left(\mathrm{pH}, \mathrm{CaCO}_{3}, \mathrm{Ks}\right)$ were not found significant statistically $(\mathrm{p} \geq 0.05)$. In general, it was determined that the effect of the leonardite type on the parameters investigated was not significant $(p \geq 0.05)$.
\end{abstract}

Keywords: Leonardite, soil, aggregate stability, organic matter, porosity

(C) 2021 Türkiye Toprak Bilimi Derneği. Her Hakkı Saklıdır

* Sorumlu yazar:

Tel. : : $02862180018 / 23009$

E-posta : rilay@comu.edu.tr
Gelis Tarihi : $\quad 16$ Subat 2021

Kabul Tarihi : $\quad 14$ Nisan 2021
e-ISSN : $2146-8141$

DOI : $10.33409 /$ tbbbd.881352 


\section{Giriş}

Organik madde toprakların fiziksel, kimyasal ve biyolojik özelliklerini iyileștirmesi nedeniyle tarımsal üretim alanlarının sürdürülebilir kullanımında son derece önemlidir. Nitekim organik madde toprak kalite yönetim sistemlerinde de, toprağın biyolojik özellikleri iyileștirmesi, bitki besin maddesi kaynağı olması, toprak strüktüründeki fonksiyonları ile birlikte yüksek agregat stabilitesi ve düșük hacim ağırlığı gibi özelikleri bakımından en önemli toprak kalite faktörü olarak kabul edilmektedir (Arshad ve Martin, 2002; Acosta-Martínez ve ark., 2003; Pritchett ve ark., 2011). Birçok çalışmada, toprak organik maddesinin agregatlaşma, suya dayanıklı agregat oluşumuna etkisi, suyun infiltrasyonu, hidrolik iletkenlik ve sıkışma gibi toprak özelliklerini iyileştirici etkisi arasında güçlü ilişkiler bulunmuştur (Chaney ve Swift, 1984; Blair ve ark., 2006a, 2006b; Kavdır ve ark., 2005; Whitbread ve ark., 2000; İlay ve Kavdir, 2018).

Toprakta organik karbon kaynağını bitkisel ve hayvansal atıklar oluşturmaktadır. Ancak, tarımsal alanlar başta olmak üzere topraklarda organik karbon stokları, toprak tekstürü, toprak işleme, topografya, iklimsel faktörler ve bitkisel üretim gibi birçok nedene bağlı olarak günden güne azalabilmektedir. Bu sebeple toprak kalitesinin bozulmaması, üretimin sürdürülebilir olması için hayati öneme sahip olan organik maddenin topraklara tekrar kazandırılması veya azalmasını engelleyecek önlemlerin alınması gerekmektedir. Hasat atıkları, hayvansal atıklar, gıda sanayi atıkları, hayvansal gübreler ve kompost gibi birçok organik materyal toprağa ilave edilerek, karbonun toprakta tutulması ve depolanması, toprağın fiziksel, kimyasal ve biyolojik özelliklerini iyileștirmesi nedeniyle önemlidir.

Organik materyallerden toprak düzenleyici olarak en çok tercih edilenlerden biri olan leonardit; organik maddelerin kömürleşme süreçlerinden etkilenmeyerek oksitlenmesiyle oluşan ve humik asitçe zengin doğal bir materyaldir. Humik asitçe zengin olması ve yüksek karbon içeriği toprak ıslahı ve bitkisel üretim açısından önemli bir yer tutmaktadır. Bununla birlikte, toprakta ve sedimentlerdeki organik karbon; kaynağın hızlı, yavaş ve ileri derecede ayrışma oranları gibi özellikleri bakımından çok geniş çeşitliliğe sahiptir (Schumacher, 2002). Bu sebeple de organik materyallerin toprak özelliklerine etkisi farklı olabilmektedir.

Bu çalışmada; Kayseri-Develi (DL) ve Çanakkale-Yenice (YL) olmak üzere 2 farklı bölgeden temin edilen leonarditin kumlu tın bünyeye sahip toprağın organik maddesi $(\mathrm{OM})$, toprak reaksiyonu $(\mathrm{pH})$, toprak elektriksel iletkenliği (EC), kireç içeriği $\left(\mathrm{CaCO}_{3}\right)$, kuru hacim ağırlığı (dB), hidrolik iletkenliği (Ks), agregat stabilitesi (AS) ve toprak boşluk hacmi (P) gibi toprak özellikleri üzerine etkileri incelenmiştir.

\section{Materyal ve Yöntem}

Çalışmada kullanılan leonardit materyalleri Kayseri ili Develi ve Çanakkale ili Yenice ilçesinde bulunan işletmelerden temin edilmiştir (Şekil 1-2). Çalışmada kullanılan toprak ise ÇOMÜ- Ziraat Fakültesi binası yanındaki kumtaşı-kil taşı ardalanmalı ana materyal üzerinde oluşmuş arazideki profilin 0-30 cm derinliğinden alınmıștır (Çizelge 1). Tesadüf parselleri deneme desenine göre iki tekerrürlü olarak yürütülen çalışmada, iki çeşit leonardit ağırlıkça beş farklı dozda (\%4, \%8, \%12, \%16, \%20) SL bünyeye sahip toprak ile karışımın toplam ağırlığı 1 kg olacak șekilde karıștırılmıștır. Plastik saksılara (No:2) konulan karıșımların nem seviyesi tarla kapasitesine getirilmiş sonrasında 15 günde bir olacak șekilde her bir saksıya $200 \mathrm{ml}$ su eklenerek üç ay süresince plastik sera koşullarında inkübe edilmiştir. Toprak örneğinin tekstür analizi Bouyoucos, (1951)'de belirtilen esaslara göre hidrometre yöntemiyle yapılmış ve tekstür sınıfı belirlenmiştir. Toprak reaksiyonu (pH) ve elektriksel iletkenlik (EC) değerleri 1:2.5 toprak-su solüsyonunda pH metre ve EC metre cihazlarıyla belirlenmiştir (Allison ve Richards, 1954). Deneme kapsamında toprakların $\mathrm{CaCO}_{3}$ içerikleri Scheibler kalsimetresi ile yüzde (\%) olarak belirlenmiştir (Schlichting ve Blume, 1966). Toprakların hidrolik iletkenlikleri, $100 \mathrm{~cm}^{3}$ hacme sahip çelik silindir yardımıyla alınan bozulmamış toprak örneklerinde sature haldeyken belirlenmiștir (Amoozegar ve Warrick, 1986). 1-2 mm agregatların suya dayanıklılıkları Kemper ve Rosenau (1986)'da belirtildiği şekilde tespit edilmiştir. Örneklerin kuru hacim ağırlıkları (dB), bozulmamış toprak örneklerinde hesaplanmıştır (Blake, 1965). Çalışma kapsamında toprak ve karışımların organik madde kapsamları Smith ve Weldon, (1941) yöntemi ile belirlenmiștir. Toprakların toplam boşluk hacmi (P), örneklerin kuru hacim ağırlıkları ve ortalama tane yoğunluğundan yararlanılarak hesaplanmıştır. Çalışma kapsamındaki elde edilen verilere çeşit ve dozun etkisi tek yönlü varyans analizi ve ortalamalar arsındaki farklar ise Duncan çoklu karşılaştırma testi $(\mathrm{p} \leq 0.05)$ kullanılarak belirlenmiştir. İstatistiksel analizlerin yapılmasında SPSS 17.0 paket programı kullanılmıştır. 


\begin{tabular}{|c|c|c|c|c|c|c|}
\hline Materyal & pH & $\begin{array}{c}\text { EC } \\
\left(\mu S \mathrm{~cm}^{-1}\right)\end{array}$ & $\begin{array}{c}\mathrm{CaCO}_{3} \\
(\%)\end{array}$ & $\begin{array}{c}\mathrm{dB} \\
\left(\mathrm{g} \mathrm{cm}^{-3}\right)\end{array}$ & $\begin{array}{l}\text { Tekstür } \\
\text { Sınıfı }\end{array}$ & $\begin{array}{c}\text { Humik+ Fulvik Asit } \\
(\%)^{*}\end{array}$ \\
\hline Toprak & 8.22 & 245 & 6.19 & 1.40 & $\begin{array}{l}\text { Kumlu Tın } \\
\text { (SL) }\end{array}$ & - \\
\hline $\begin{array}{l}\text { Develi Leonarditi } \\
\text { (DL) }\end{array}$ & 4.15 & 2200 & 0 & - & - & 40 \\
\hline $\begin{array}{l}\text { Yenice } \\
\text { Leonarditi (YL) }\end{array}$ & 4.70 & 2610 & 0 & - & - & $40-50$ \\
\hline
\end{tabular}

*Tescil belgesine göre verilmiş değerlerdir.

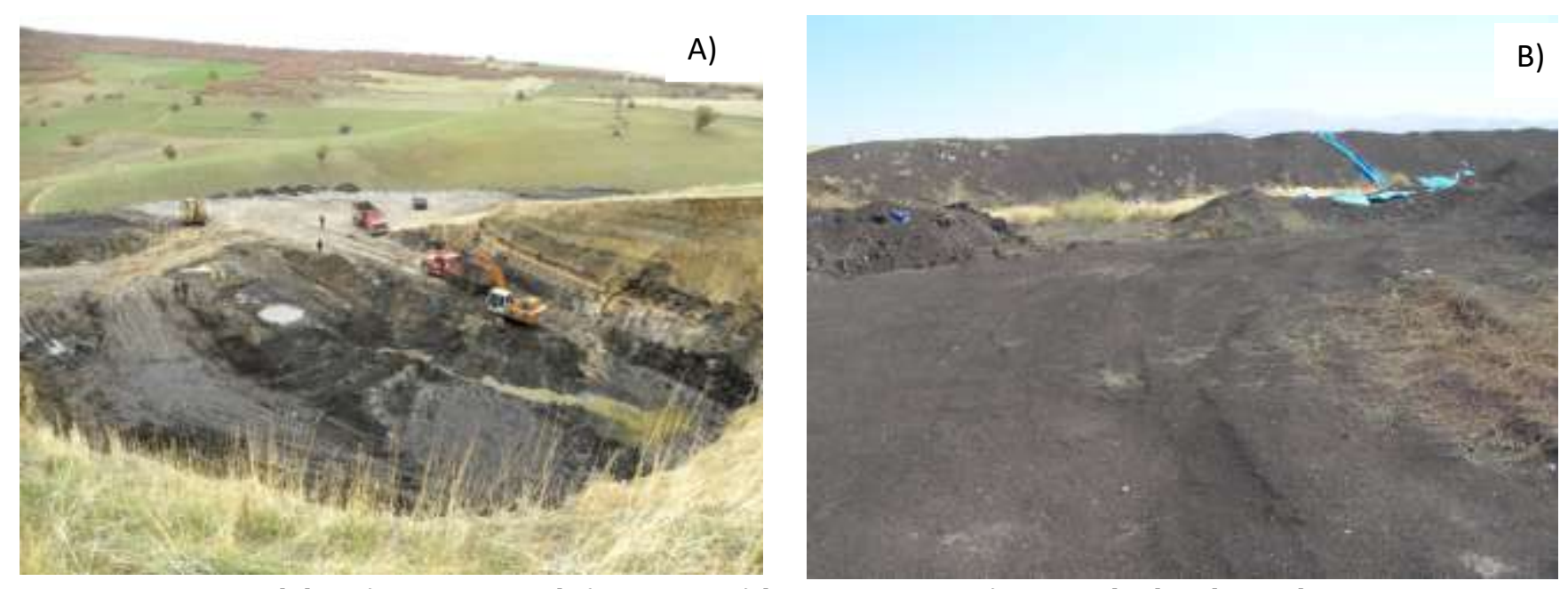

Şekil 1. A)Kayseri-Develi (Tavşantepe) leonartit ocağı, B) Leonardit depolama alanı

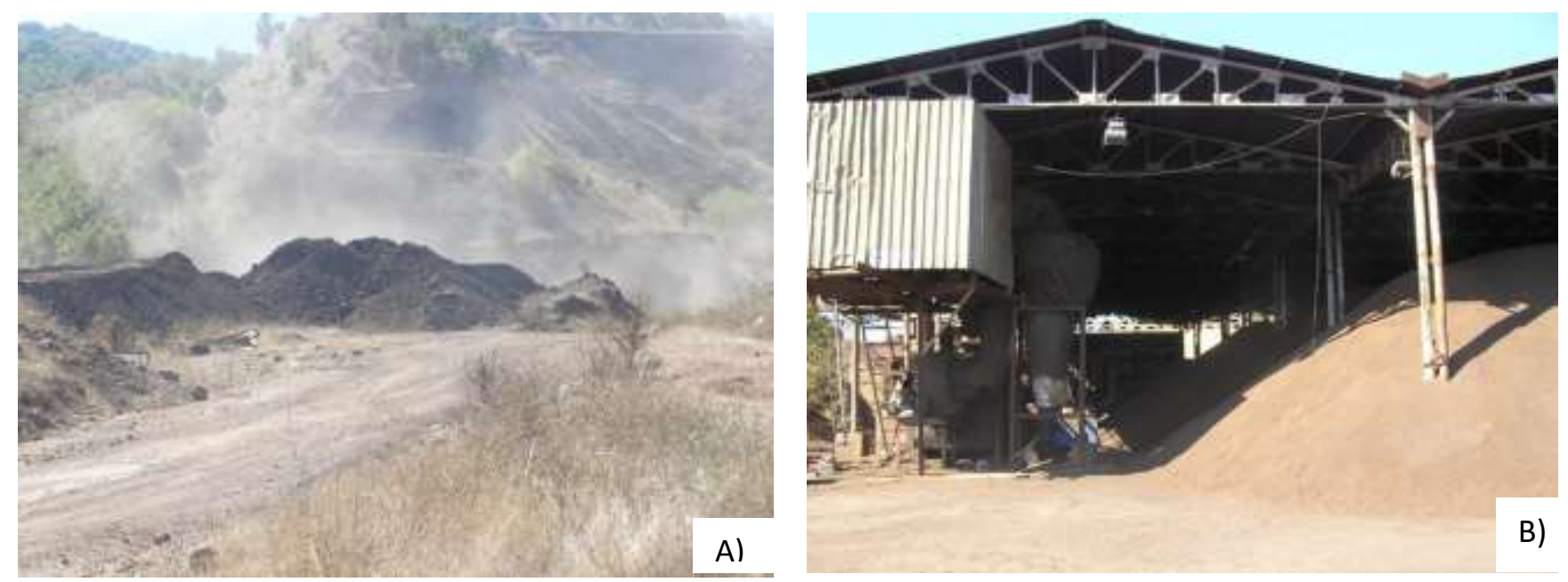

Şekil 2. A) Çanakkale Yenice-Kalkım leonardit ocağı, B) Leonardit işleme tesisi

\section{Bulgular ve Tartışma}

Çalışma kapsamında kullanılan leonardit çeşitleri ve uygulama dozlarının topraklarda tespit edilen parametrelere etkilerine ait istatistiksel değerlendirme Çizelge 2'de, grafikler ise Şekil 3 ve 4 'te sunulmuştur. Çizelge 2'den de görüleceği üzere genel olarak DL ve YL uygulamalarının toprağın $\mathrm{EC}, \mathrm{OM}, \mathrm{dB}, \mathrm{AS}$ ve $\mathrm{P}$ parametreleri üzerine etkisinin önemli olduğu tespit edilmiştir $(\mathrm{p} \leq 0.05)$. Bununla birlikte her iki leonardit çeşidine ait dozlarının EC, OM, Ks, AS parametreleri üzerine etkisinin istatistiksel olarak önemli olduğu tespit edilmiştir $(\mathrm{p} \leq 0.05)$. Yine YL çeşidine ait farklı doz uygulamasının toprak $\mathrm{dB}$ ve $\mathrm{P}$ değerleri üzerine etkisi istatistiksel olarak önemli bulunmuştur ( $\mathrm{p} \leq 0.05)$ (Çizelge 2).

pH: Leonardit çeşit ve dozlarının toprak pH'sına etkilerine ait değerler Çizelge 2 ve Şekil 3A'da görülmektedir. Tüm uygulamalar incelendiğinde leonardit çeşit ve dozunun $\mathrm{pH}$ üzerine etkisinin istatistiksel öneme sahip olmadığı görülmektedir. Bunun yanında en düşük toprak pH'sı \%20 DL uygulamasıyla elde edilirken, en yüksek pH kontrol uygulamasında yani leonardit bulunmayan toprakta tespit edilmiştir. 
Çizelge 2. Genel olarak leonardit çeşitlerinin toprak özellikleri üzerine etkileri

\begin{tabular}{|c|c|c|c|c|c|c|c|c|c|}
\hline \multirow{2}{*}{\multicolumn{2}{|c|}{ Uygulamalar }} & \multicolumn{8}{|c|}{ Toprak Parametreleri } \\
\hline & & pH & $\begin{array}{c}E C \\
\left(\mu \mathrm{cm}^{-1}\right)\end{array}$ & $\begin{array}{l}\text { OM } \\
(\%)\end{array}$ & $\begin{array}{c}\mathrm{CaCO}_{3} \\
(\%)\end{array}$ & $\begin{array}{c}\mathrm{dB} \\
\left(\mathrm{gr} \mathrm{cm}^{-3}\right)\end{array}$ & $\begin{array}{c}\text { Ks } \\
\text { (cm } \text { saat }^{-1} \text { ) }\end{array}$ & $\begin{array}{c}\text { AS } \\
(\%)\end{array}$ & $\begin{array}{c}P \\
(\%)\end{array}$ \\
\hline \multicolumn{2}{|c|}{ Kontrol } & $8.22 \pm 0.14$ & $245.07 \pm 62.53 \mathrm{a}$ & $0.61 \pm 0.07 \mathrm{a}$ & $6.19 \pm 0.68$ & $1.40 \pm 0.02 \mathrm{a}$ & $2.10 \pm 0.54 \mathrm{~b}$ & $34.50 \pm 0.40 \mathrm{a}$ & $47.17 \pm 0.37 \mathrm{a}$ \\
\hline \multicolumn{2}{|c|}{ DL } & $7.74 \pm 0.10$ & $829.20 \pm 84.41 \mathrm{~b}$ & $1.98 \pm 0.21 \mathrm{~b}$ & $5.72 \pm 0.20$ & $1.27 \pm 0.02 \mathrm{~b}$ & $1.27 \pm 0.18 \mathrm{ab}$ & $51.16 \pm 2.85 b$ & $51.82 \pm 0.68 \mathrm{~b}$ \\
\hline \multicolumn{2}{|r|}{ YL } & $7.70 \pm 0.13$ & $819.80 \pm 92.62 \mathrm{~b}$ & $1.87 \pm 0.27 \mathrm{~b}$ & $6.04 \pm 0.22$ & $1.24 \pm 0.03 \mathrm{~b}$ & $1.08 \pm 0.18 \mathrm{a}$ & $52.29 \pm 0.92 \mathrm{~b}$ & $52.88 \pm 0.99 \mathrm{~b}$ \\
\hline \multicolumn{2}{|c|}{ F Değeri } & $2.66^{*}$ & $6.09^{* *}$ & $4.34^{* *}$ & $0.72^{*}$ & $3.97^{* *}$ & $2.52 *$ & $6.44^{* *}$ & $3.97^{* *}$ \\
\hline \multirow{6}{*}{ DL } & $\% 0$ & $8.22 \pm 0.14$ & $45.07 \pm 62.53 \mathrm{a}$ & $0.61 \pm 0.07 \mathrm{a}$ & $6.19 \pm 0.68$ & $1.40 \pm 0.01$ & $2.1 \pm 0.54 \mathrm{~b}$ & $34.50 \pm 0.40 \mathrm{a}$ & $47.17 \pm 0.38$ \\
\hline & $\% 4$ & $7.92 \pm 0.18$ & $422.00 \pm 80.00 \mathrm{~b}$ & $1.24 \pm 0.23 \mathrm{ab}$ & $6.43 \pm 0.32$ & $1.25 \pm 0.06$ & $1.32 \pm 0.06 \mathrm{~b}$ & $34.98 \pm 0.2$ & $52.89 \pm 2.09$ \\
\hline & $\% 8$ & $7.84 \pm 0.31$ & $680.50 \pm 4.50 \mathrm{c}$ & $1.80 \pm 0.35 \mathrm{~b}$ & $5.94 \pm 0.08$ & $1.34 \pm 0.07$ & $1.74 \pm 0.06 \mathrm{~b}$ & $51.67 \pm 1.74 \mathrm{~b}$ & $49.41 \pm 2.78$ \\
\hline & $\% 12$ & $7.46 \pm 0.015$ & $936.5 \pm 93.50 \mathrm{~d}$ & $1.59 \pm 0.16 \mathrm{~b}$ & $6.07 \pm 0.29$ & $1.275 \pm 0.01$ & $1.26 \pm 0.12 \mathrm{~b}$ & $54.57 \pm 0.22 \mathrm{~b}$ & $51.96 \pm 0.23$ \\
\hline & $\% 16$ & $7.565 \pm 0.415$ & $977.5 \pm 12.50 \mathrm{de}$ & $2.44 \pm 0.07 \mathrm{c}$ & $5.10 \pm 0.2$ & $1.25 \pm 0.01$ & $0.27 \pm 0.03 \mathrm{a}$ & $55.06 \pm 1.5$ & $52.89 \pm 0.23$ \\
\hline & $\% 20$ & $7.89 \pm 0.005$ & $1129.5 \pm 5.50 \mathrm{e}$ & $2.83 \pm 0.20 \mathrm{c}$ & $5.05 \pm 0.39$ & $1.27 \pm 0.02$ & $1.74 \pm 0.00 \mathrm{~b}$ & $59.56 \pm 0.29 \mathrm{c}$ & $51.96 \pm 0.70$ \\
\hline \multicolumn{2}{|c|}{ F Değeri } & $1.72^{*}$ & $47.60^{* *}$ & $20.85^{* *}$ & $1.39 *$ & $2.44^{*}$ & $7.73^{* *}$ & $126.80^{* *}$ & $2.44^{*}$ \\
\hline \multirow{6}{*}{ YL } & $\% 0$ & $8.22 \pm 0.14$ & $245.07 \pm 62.53 \mathrm{a}$ & $0.61 \pm 0.07 \mathrm{a}$ & $6.19 \pm 0.68$ & $1.40 \pm 0.01 \mathrm{c}$ & $2.1 \pm 0.54 \mathrm{c}$ & $34.50 \pm 0.40 \mathrm{a}$ & $47.17 \pm 0.38 \mathrm{a}$ \\
\hline & $\% 4$ & $8.15 \pm 0.13$ & $413.5 \pm 10.50 \mathrm{a}$ & $0.86 \pm 0.10 \mathrm{a}$ & $6.83 \pm 0.00$ & $1.14 \pm 0.02 \mathrm{a}$ & $1.95 \pm 0.03 \mathrm{bc}$ & $53.46 \pm 0.65 \mathrm{bc}$ & $57.07 \pm 0.70 \mathrm{c}$ \\
\hline & $\% 8$ & $7.78 \pm 0.28$ & $634 \pm 26.00 \mathrm{~b}$ & $1.28 \pm 0.05 \mathrm{ab}$ & $6.10 \pm 0.08$ & $1.31 \pm 0.03 \mathrm{bc}$ & $0.96 \pm 0.12 \mathrm{ab}$ & $49.05 \pm 0.13 \mathrm{~b}$ & $50.57 \pm 1.16 \mathrm{ab}$ \\
\hline & $\% 12$ & $7.84 \pm 0.35$ & $859.5 \pm 44.50 \mathrm{~b}$ & $1.69 \pm 0.28 \mathrm{~b}$ & $6.39 \pm 0.44$ & $1.32 \pm 0.01 \mathrm{bc}$ & $0.72 \pm 0.12 \mathrm{a}$ & $55.10 \pm 2.71 \mathrm{c}$ & $50.10 \pm 0.23 \mathrm{al}$ \\
\hline & $\% 16$ & $7.36 \pm 0.065$ & $986 \pm 58.00 \mathrm{c}$ & $2.575 \pm 0.33 \mathrm{c}$ & $5.18 \pm 0.28$ & $1.25 \pm 0.07 \mathrm{ab}$ & $0.48 \pm 0.12 \mathrm{a}$ & $50.13 \pm 1.54 \mathrm{bc}$ & $52.89 \pm 2.55 b$ \\
\hline & $\% 20$ & $7.36 \pm 0.17$ & $1206 \pm 44.00 \mathrm{~d}$ & $2.93 \pm 0.26 \mathrm{c}$ & $5.71 \pm 0.49$ & $1.22 \pm 0.06 \mathrm{ab}$ & $1.29 \pm 0.39 \mathrm{abc}$ & $53.72 \pm 1.22 \mathrm{bc}$ & $53.82 \pm 2.09 \mathrm{~b}$ \\
\hline \multicolumn{2}{|c|}{ F Değeri } & $3.45^{*}$ & $53.68^{* *}$ & $24.10^{* *}$ & $1.20 *$ & $5.46^{* *}$ & $5.34^{* *}$ & $29.65^{* *}$ & $5.45^{* *}$ \\
\hline
\end{tabular}

$\pm:$ Standart hata; *Önemli değil $(\mathrm{p} \geq 0.05)$; $^{* *} 0.05$ seviyesinde önemli; $\mathrm{pH}$ : Toprak reaksiyonu; EC: elektriksel iletkenlik; OM: Organik madde; Ks: Hidrolik iletkenlik; dB: Kuru hacim ağırlı̆̆ı; AS: agregat stabilitesi;P: Toplam boşluk hacmi.

Çizelge 2 ve Şekil 3A'da görüleceği üzere her iki çeşit leonarditin, artan dozlarına bağlı olarak toprak pH'sinin azaldığı tespit edilmiştir. Yine Çizelge 2 incelendiğinde kontrol uygulamasına göre YL uygulamasının $\mathrm{pH}$ değerini \%6.3, DL uygulamasının ise \%5.9 daha düşürdüğü tespit edilmiştir ( $\mathrm{p} \geq 0.05)$. Bu durumun kullanılan leonarditlerin düşük $\mathrm{pH}$ değerlerine sahip olmasından kaynaklandığı düşünülmektedir (Çizelge 1). Bununla birlikte leonardit uygulama miktarı ve pH değerleri kıyaslandığında; karışımların yaklaşık \%10 daha düşük bir pH değerlerine sahip olması öngörülebilir. Ancak toprağın tamponlama özellinden net etkinin veya değişimin görülebilmesi için daha fazla sürenin geçmesi gerekmektedir. Leonardit fiziksel yapısından ziyade, içerdiği yüksek humik asit veya başka bir değişle karbon, bitki besin maddesi miktarıyla toprak veya bitki üzerinde çeşitli etkilere sahiptir. Dolayısıyla asıl etkisi humik asit sayesindedir. Ciarkowska ve ark. (2017) yaptıkları çalışmada, 5.10 pH değerine sahip kaba bünyeli bir toprağa $6.2 \mathrm{pH}$ değerine sahip humik asit uygulaması yaparak, ilk yılda kontrole göre daha yüksek pH değeri elde etmiştir. Benzer şekilde Li ve ark. (2019)' nın humik asitin toprak özelliklerine etkisini araştırdıkları çalışmada kullanılan materyalin $\mathrm{pH}$ değerine göre, uygulamanın toprak $\mathrm{pH}$ sını düşürdügü ancak bunun istatistiksel olarak önemsiz olduğunu tespit etmişlerdir. Ece ve ark. (2007) yaptıkları çalışmada, leonardit uygulamasının $\mathrm{pH}$ değerlerine istatistiksel olarak etkisinin önemli olmadığını ve bunun yıllara göre de değişmediğini bildirmişlerdir. Pekcan ve ark. (2017) yaptıkları çalışmada 28 adet farklı leonartin pH değerinin 2.35 ile 7.76 arasında değiştiğini tespit etmişlerdir. Bu sebeple birçok kaynaktan elde edilebilen leonardit kısa sürede pH'yi arttırmak için veya düşürmek için düzenleyici olarak kullanılabilir.

EC: Leonardit uygulamalarının EC değerleri üzerine etkilerine ait veriler Çizelge 2 ve Şekil 3B'de sunulmuştur. Leonardit uygulaması ve bunlara ait uygulama dozlarının toprakların EC değeri üzerine etkisi önemli bulunmuştur ( $\mathrm{p} \leq 0.05)$ ) 3 aylık inkübasyon sonunda en düşük EC değeri kontrol uygulamasında, en yüksek değer ise \%20YL uygulamasında tespit edilmiştir. EC değerlerinde pH değerlerinin tersine, uygulanan doza bağlı olarak artışlar görülmektedir. Çizelge 1'de görüldüğü üzere bu durumun kullanılan materyalin yani leonarditin özelliğine bağlı olarak arttığı açıktır. Ayrıca zaman ve neme bağlı olarak toprak ve leonarditin içerdiği tuzların daha fazla çözünebilir duruma geçmesi EC değerlerinin artmasına ayrıca bir sebep olarak gösterilebilir. DL uygulamasıyla ortalama $829.20 \mu \mathrm{S} \mathrm{cm}^{-1}$; YL uygulamasiyla ise $819.80 \mu \mathrm{S} \mathrm{cm}{ }^{-1}$ EC değeri tespit edilmiştir. Her ne kadar leonardit uygulamasıyla EC değeri artış meydana gelse de en yüksek dozda dahi zararlı olabilecek tuzluluk seviyelerine (4 $\mathrm{dS} \mathrm{m}^{-1}$ ) ulaşılmamıştır. Kontrol uygulamasıyla 
kıyaslandığında EC değeri DL uygulaması ile \%238 YL ile ise \%234 düzeyinde artmıștır (Çizelge 2). Ece ve ark. (2007) yaptıkları çalışmada, leonardit uygulamasıyla EC değerlerinde artış tespit etseler de istatistiksel olarak etkisinin önemli olmadığını bildirmişlerdir.

A) $(\mathrm{F}: 2.66 ; \mathrm{p} \geq 0.05)$

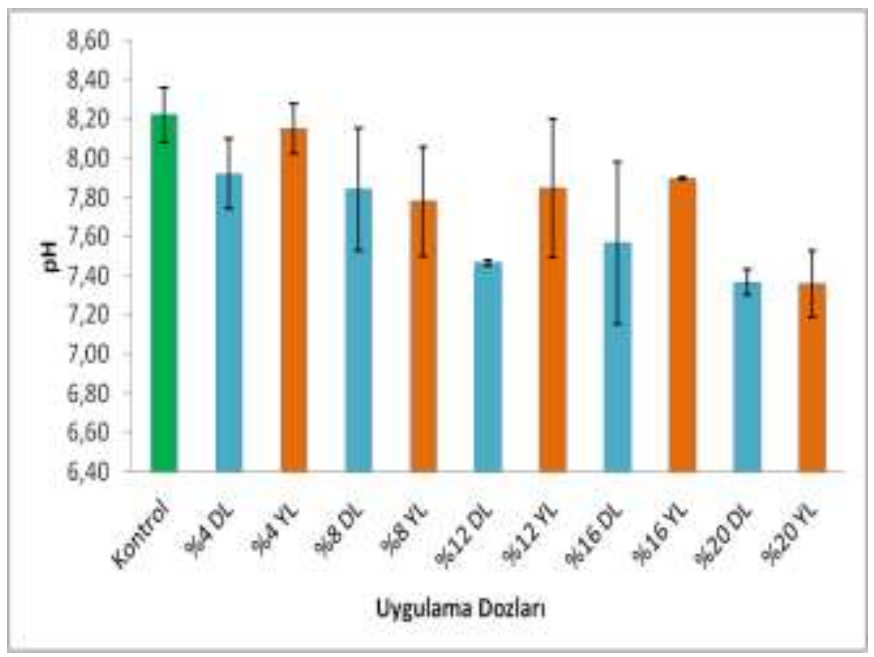

C) $(\mathrm{F}: 4.34 ; \mathrm{p} \leq 0.05)$

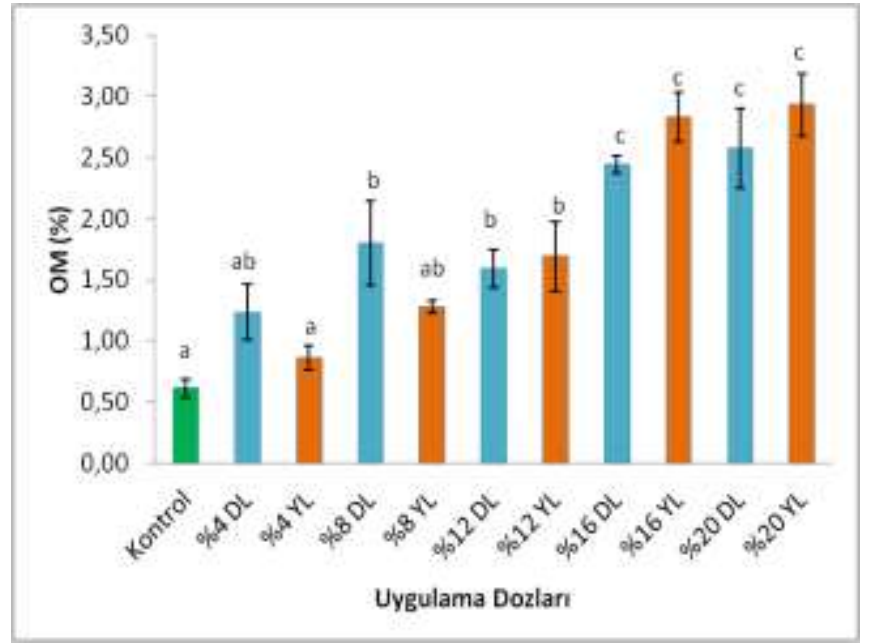

B) $(\mathrm{F}: 6.09 ; \mathrm{p} \leq 0.05)$

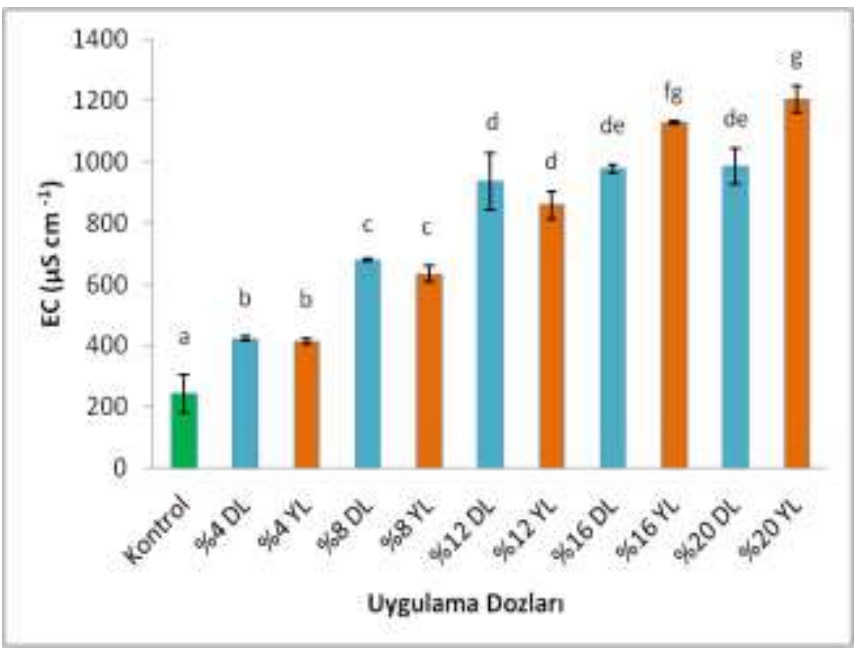

D) ( $F: 0.72 ; p \geq 0.05)$

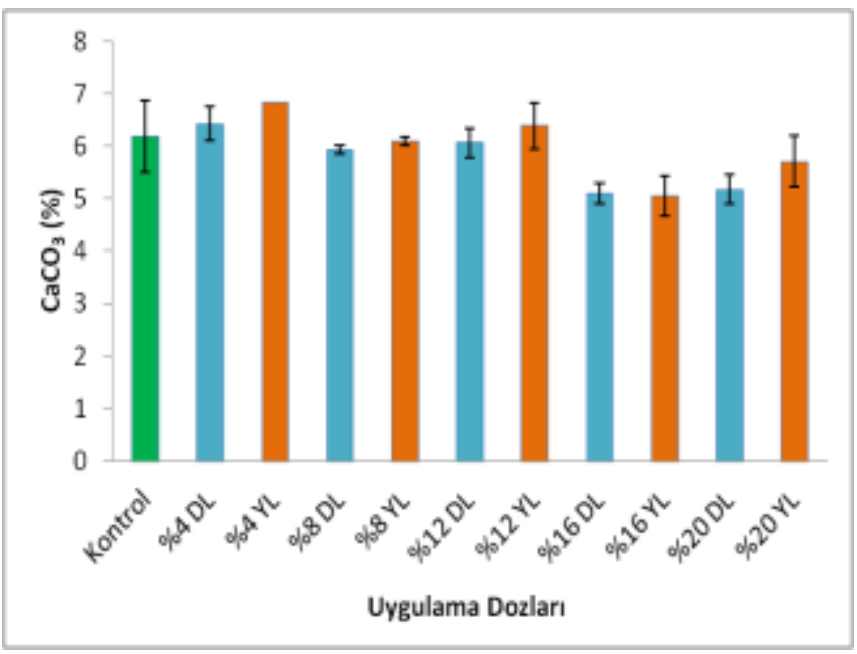

Şekil 3. Leonardit çeşitlerinin dozlara bağlı toprakların A) toprak reaksiyonuna, B) elektriksel iletkenliğine C)organik madde kapsamına, D) kireç kapsamına etkisi

OM: Leonardit çeșitleri ve dozlarının toprak organik maddesi üzerine etkileri Çizelge 2 ve Şekil 3C'de sunulmuștur. Görüldüğü üzere iki leonardit uygulaması arasında istatistiksel fark olmasa da kontrole göre toprakların OM içerikleri önemli düzeylerde artmıștır ( $\mathrm{p} \leq 0.05)$. Ayrıca, uygulanan dozların OM miktarı üzerine etkileri istatistiksel olarak önemlidir ( $\mathrm{p} \leq 0.05$ ). En yüksek OM değeri \% 20 YL uygulamasındaki karışımda tespit edilmiştir. OM içeriği kontrole göre yaklaşık 5 kat yüksek bulunmuştur. DL ve YL uygulamalarıyla OM değerleri kontrole göre sırasıyla \%222, ve \%204 daha fazla tespit edilmiştir. Her ne kadar çeşitler arasında istatistiksel bir fark bulunmasa da bu değer farkının sebebi, DL 'nin OM içeriğinin YL ye daha fazla olması gösterilebilir (Çizelge 1). Benzer bir çalışmada humik asit uygulamasıyla kaba bünyeli toprağın toplam karbon miktarının arttığı tespit edilmiştir (Ciarkowska ve ark., 2017). Başka bir çalışmada ise; humik asit uygulamasıyla ilk yıl \%4.4 organik madde artışı tespit edilirken, bu oran üç yıl sonunda yaklaşık \%37 olmuştur (Li ve ark., 2019). Ece ve ark. (2007) çalışmalarında, leonardit uygulamasının toprak organik maddesini kontrole göre önemli düzeyde $(\mathrm{p}<0.01)$ arttırdığını ancak leonardit uygulamaları arasındaki farkın önemsiz olduğunu bildirmişlerdir.

$\mathrm{CaCO}_{3}$ : Leonardit çeşit ve dozlarının toprak $\mathrm{CaCO}_{3}$ miktarları üzerine etkileri Şekil 3D'de verilmiştir. Genel olarak bakıldığında, leonardit uygulamalarıyla toprak $\mathrm{CaCO}_{3}$ miktarlarının azalma eğiliminde olduğu söylenebilir. Kontrol uygulamasına göre kıyaslandığında $\mathrm{CaCO}_{3}$ miktarlarındaki azalma DL uygulamasıyla \%7.65, YL uygulamasıyla \%2.40 düzeyinde gerçekleşmiştir (Çizelge 2). Ece ve ark. (2007) yaptıkları çalışmada, leonardit uygulamasının kireç miktarlarını istatistiksel olarak etkisinin önemsiz olduğunu 
bildirmişlerdir. Leonarditin içerdiği humik asit, topraktaki $\mathrm{CaCO}_{3}$ bileşiklerini parçalar ve $\mathrm{CO}_{2}$ açığa çıkmasına sebep olabilir. $\mathrm{CO}_{2}$ bitki gelişiminde gerekli ve etkili olmasının yanı sıra topraktaki besin elementlerinin serbest kalmasına etki yapan karbonik asit $\left(\mathrm{H}_{2} \mathrm{CO}_{3}\right)$ oluştururlar. Bu sebeple, $\mathrm{CaCO}_{3}$ miktarında düşüşlerin meydana geldiği düşünülmektedir.

dB: Toprağın fiziksel özelliklerinden kuru hacim ağırlığı (dB) üzerine leonardit uygulaması ve dozlara bağlı etkisi Çizelge 2 ve Şekil 4A'da gösterilmiștir. Kontrol uygulamasıyla klyaslandığında, leonardit uygulamasıyla $\mathrm{dB}$ değerlerindeki değișimin istatistiksel olarak önemli $(\mathrm{p} \leq 0.05)$ olduğu görülmekte olup, DL uygulamasıyla \%9.28, YL uygulamasıyla \%11.42 oranında azalmıştır. Buna rağmen leonardit çeşitlerinin toprakların $\mathrm{dB}$ değerlerine etkisi istatistiksel olarak önemsiz bulunmuştur ( $\mathrm{p} \geq 0.05$ ) (Çizelge 2). Ahmad ve ark. (2015) yaptıkları çalışmada kömürden elde edilen humik asidin farklı doz uygulamalarıyla hacim ağırlığında azalmalar tespit etmişlerdir. Benzer șekilde toprağa uygulanan farklı organik materyaller ile yapılmış çeşitli çalışmalarda da dB'nin azalma eğilimde olduğu bildirilmiştir (Rasool ve ark., 2008; Hemmat ve ark., 2010; Guo ve ark., 2016).

A) (F:3.98; $\mathrm{p} \leq 0.05)$

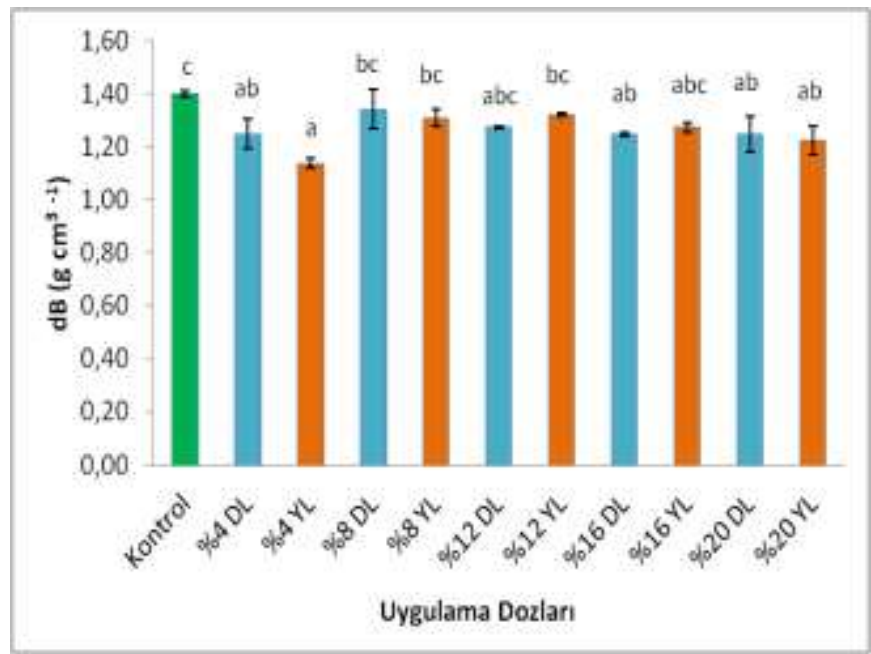

C) $(\mathrm{F}: 6.44 ; \mathrm{p} \leq 0.05)$

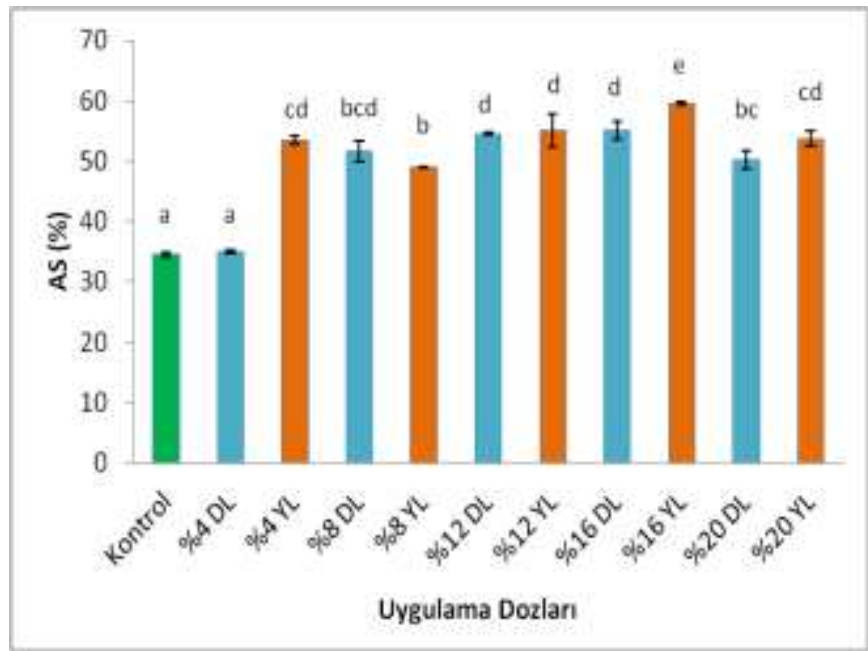

B) $(\mathrm{F}: 2.52 ; \mathrm{p} \geq 0.05)$

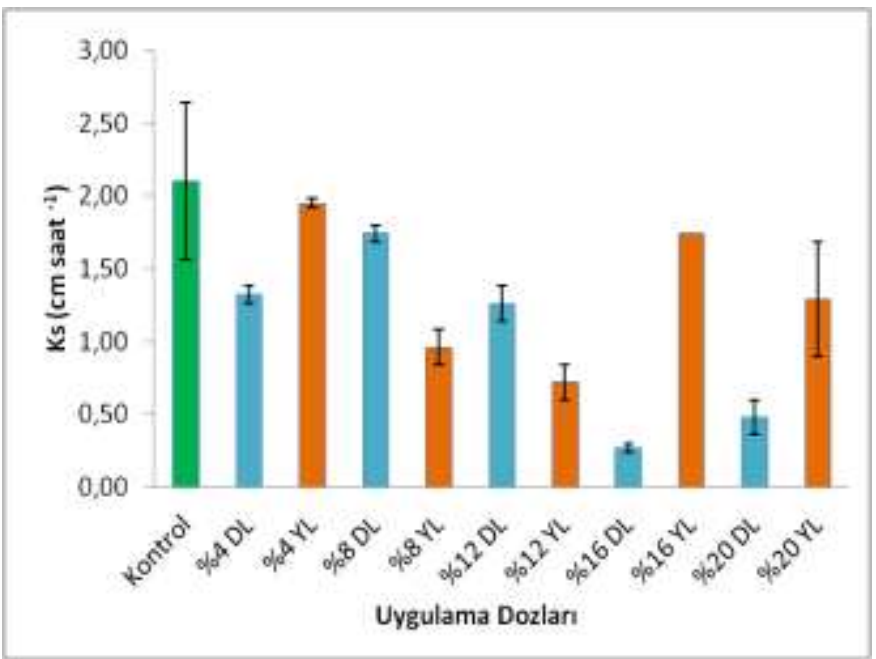

D) $(\mathrm{F}: 2.87 ; \mathrm{p} \leq 0.05)$

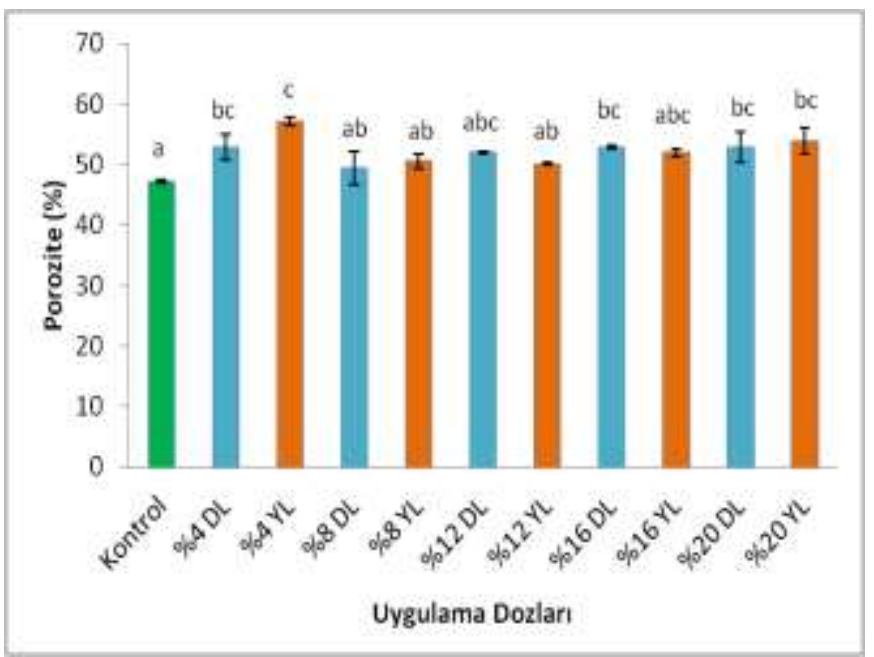

Şekil 4. Leonardit çeşitlerinin dozlara bağlı toprakların A) kuru hacim ağırlığına B) hidrolik iletkenliğine C) agregat stabilitesine C) boşluk hacmine etkisi.

Ks: Hidrolik iletkenlik (Ks) değerlerine ait grafik ve veriler Şekil 4B ve Çizelge 2'de sunulmuştur. Kontrol uygulamasıyla kıyaslandığında her iki leonardit uygulamasıyla Ks değerlerinde düşüşler gözlenmiştir. En yüksek Ks ortalaması kontrol uygulamasında, en düşük Ks değeri ise \%16 DL uygulamasıyla elde edilmiştir. Sonrasında ise sırasıyla DL \%20 ve YL \%12 uygulamasında düşük Ks değerleri elde edilmiştir. Ks değerleri kontrole göre YL uygulamasıyla ortalama \%48.57 azalırken, DL uygulamasıyla \%39.71 azalmıştır (Çizelge 2). Ks; toprak tekstürü, strüktür tipi, organik materyal çeşidi, OM miktarı, işleme teknikleri gibi birçok etkene göre değişebilmektedir. Lado ve ark. (2004) \%2.5 ve \%3.5 OM içeren SL tekstürlü topraklarda Ks değerini 
yüksek OM içeriğine sahip olanda daha yüksek tespit etmişlerdir. Barnes ve ark. (2014) yaptıkları çalışmada biyokömür uyguladığı kum ve organik toprağın Ks değerinin azaldığını, biyokömür uygulanan kilin ise Ks değerinin arttığını bildirmişlerdir. Benzer șekilde Nemes ve ark. (2005) OM ve Ks arasında negatif ilişkilerin olabileceğini, toprak strüktürünün OM'nin artmasıyla modifiye olabileceğini, boşluk oranlarının değişebileceğini bu durumun da suyun geçişini sınırlayabileceğini bildirmişlerdir. Bu çalışmada Ks değerlerindeki düşüşün sebebi ise leonarditin boşluk oranlarını etkilenmesinden dolayı su geçişinin sınırlanması olarak gösterilebilir.

AS: Leonardit uygulamaları ve dozlarının suya dayanıklı agregat stabilitesi (AS) üzerine etkilerine ait veriler Çizelge 2 ve Şekil 4C'de sunulmuştur. Buna göre, tüm leonardit uygulamalarıyla AS değerlerinin arttığı görülmektedir. En yüksek AS değeri \%16 YL uygulamasında tespit edilmiştir. Genel olarak kontrolle kıyaslandığında, AS değerleri DL uygulamalarıyla \%48.3, YL uygulamasıyla ise \%51.6 daha fazla bulunmuştur. Toprak organik maddesi, dayanıklı agregatların oluşmasında merkezi bir öneme sahip oluğundan, organik madde ve suya dayanıklı agregatlar arasında yakın bir ilişki vardır. Nitekim İlay ve Kavdir (2018) yaptıkları çalışmada topraktaki karbon ve AS arasında yakın ilişki tespit etmişlerdir. Ahmad ve ark. (2015) kömürden elde edilen humik asidin, agregat stabilitesini arttırdığını tespit etmişlerdir. Aynı şekilde Chaney ve Swift (1984), Barral ve ark. (1998) toprak organik madde içeriği ile agregat stabilitesi arasında genellikle güçlü bir korelasyon olduğu bildirilmiştir. Birçok çalışmada toprağa çeşitli organik madde ilavesiyle agregat stabilitesinin arttığı rapor edilmiştir (Kavdir ve Killi, 2008; Herath ve ark. 2013; İlay ve ark., 2019). Bu bağlamda leonardit uygulamasıyla artan organik karbon içeriğine bağlı olarak AS değerlerinin de arttı̆̆ söylenebilir.

P: Çalışmada tespit edilen porozite (P) değerlerine ait veriler Çizelge 2 ve Şekil 4D'de sunulmuştur. Genel olarak leonardit uygulamasıyla değerlerin artış eğiliminde olduğu görülmektedir. En düşük P değeri kontrol uygulamasında tespit edilmiștir. Kontrolle kıyaslandığında, DL uygulamalarıyla P ortalama değerinin \%9.86, YL uygulamalarıyla ise \%12.10 daha yüksek olduğu belirlenmiştir ( $\mathrm{p} \leq 0.05)$. İki leonardit çeşidi kendi içinde değerlendirildiğinde ise; DL uygulamasındaki dozlar arasında istatistiksel bir fark bulunamazken, YL uygulamasındaki dozun etkisi önemli bulunmuştur (Çizelge 2). Genel olarak toprakta organik madde ile porozite arasında pozitif ilişkilerin olduğu bilinmektedir. Bu sebeple çalışma kapsamındaki porozitenin artışı leonardit uygulamasından kaynaklanmaktadır. Benzer çalışmalarda farklı organik materyallerin toprağa uygulanması ile de P değerlerinde artışlar raporlanmıștır (Obi ve Ebo, 1995; Marinari ark., 2000; Rasool ve ark., 2008; Toková ve ark., 2020).

\section{Sonuç}

Daha önceki yapılan çalışmalar incelendiğinde, çoğunlukla leonarditin, bitki gelişimi, ürün verimi, besin maddesi alınabilirliği, biyolojik özelliklere etkisi gibi araştırmalar mevcut olup, toprak özellikleri üzerine etkilerine ait çalışmalar sınırlı kalmıştır. Yapılan bu çalışmada aynı türdeki ancak iki farklı kaynaktan elde edilen birbirine yakın özelliklerde bulunan organik materyalin yani leonarditin toprağın bazı özellikleri üzerine kısa süreli etkileri araştırılmış ve araştırma sonuçları değerlendirilmiştir. Buna göre kaynakları farklı olsa da çalışmada kullanılan leonarditlerin incelenen toprak özellikleri üzerine etkilerinde önemli bir fark bulunmamıștır. Genel olarak her iki çeşidin de toprakların EC, OM, dB, AS ve P özellikleri üzerine etkisi önemli bulunurken; $\mathrm{pH}, \mathrm{CaCO}_{3}$ ve Ks özelliklerine etkisi önemsiz bulunmuştur. $\mathrm{Bu}$ bağlamda; leonardit kullanımının 3 ay gibi kısa bir sürede kumlu tın bünyeli toprağın OM, AS ve EC (besin maddesi) arttırması, Ks değerini ise düşürmesi gibi olumlu sayllabilecek nedenlerle her iki materyalin de hafif bünyeli, organik maddesi düşük olan topraklarda düzenleyici olarak kullanımının uygun olabileceği değerlendirilmektedir.

\section{Teşekkür}

$\mathrm{Bu}$ çalışma, lisans tezi kapsamında elde edilen verilerden yararlanılarak türetilmiştir. Kayseri Develi ilçesindeki "Buhara Leonardit" ve Çanakkale-Yenice ilçesindeki "Kazdağı Organik" işletmelerine leonardit teminleri için teşekkür ederiz.

\section{Çıkar Çatışması Beyanı}

Makale yazarları aralarında herhangi bir çıkar çatışması olmadığını beyan ederler. 


\section{Kaynaklar}

Acosta-Martínez V, Zobeck TM, Gill TE, Kennedy AC, 2003. Enzyme activities and microbial community structure in semiarid agricultural soils. Biology and Fertility of Soils 38:216-227.

Ahmad I, Ali S, Khan KS, Hassan F, Bashir K, 2015. Use of coal derived humic acid as soil conditioner to improve soil physical properties and wheat yield. International Journal of Plant \& Soil Science 5: 268-275.

Allison LE, Richards LA, 1954. Diagnosis and improvement of saline and alkali soils (No. 60). Soil and Water Conservative Research Branch, Agricultural Research Service, US Department of Agriculture.

Amoozegar A, Warrick AW, 1986. Hydraulic conductivity of saturated soils: field methods. Methods of Soil Analysis: Part 1 Physical and Mineralogical Methods 5: 735-770.

Arshad MA, Martin S, 2002. Identifying critical limits for soil quality indicators in agro-ecosystems. Agriculture, Ecosystems \& Environment 88:153-160.

Barnes RT, Gallagher ME, Masiello CA, Liu Z, Dugan B, 2014. Biochar-Induced Changes in Soil Hydraulic Conductivity and Dissolved Nutrient Fluxes Constrained by Laboratory Experiments. PLOS ONE 9:e108340.

Barral MT, Arias M, Guerif J, 1998. Effects of iron and organic matter on the porosity and structural stability of soil aggregates. Soil and Tillage Research 46:261-272.

Blair N, Faulkner RD, Till AR, Korschens M, Schulz, E, 2006a. Long-term management impacts on soil C, N and physical fertility: Part II: Bad Lauchstadt static and extreme FYM experiments. Soil and Tillage Research 91(1-2),39-47.

Blair N, Faulkner RD, Till AR, Poulton PR, 2006b. Long-term management impacts on soil C, N and physical fertility: Part I: Broadbalk experiment. Soil and Tillage Research 91(1-2): 30-38.

Blake GR, 1965. Bulk density. Methods of Soil Analysis: Part 1 Physical and Mineralogical Properties, Including Statistics of Measurement and Sampling 9:374-390.

Bouyoucos GJ, 1951. A recalibration of the hydrometer method for making mechanical analysis of soils 1 . Agronomy Journal 43:434-438.

Chaney K, Swift RS, 1984. The influence of organic matter on aggregate stability in some British soils. Journal of Soil Science 35:223-230.

Ciarkowska K, Sołek-Podwika K, Filipek-Mazur B, Tabak M, 2017. Comparative effects of lignite-derived humic acids and FYM on soil properties and vegetable yield. Geoderma 303:85-92.

Ece A, Saltali K, Eryiğit N, Uysal F, 2007. The effects of leonardite applications on climbing bean (Phaseolus vulgaris L.) yield and the some soil properties. Journal of Agronomy 6:480-483.

Guo L, Wu G, Li Y, Li C, Liu W, Meng J, Liu H, Yu X, Jiang G, 2016. Effects of cattle manure compost combined with chemical fertilizer on topsoil organic matter, bulk density and earthworm activity in a wheat-maize rotation system in Eastern China. Soil and Tillage Research 156:140-147.

Hemmat A, Aghilinategh N, Rezainejad Y, Sadeghi M, 2010. Long-term impacts of municipal solid waste compost, sewage sludge and farmyard manure application on organic carbon, bulk density and consistency limits of a calcareous soil in central Iran. Soil and Tillage Research 108:43-50.

Herath HMSK, Camps-Arbestain M, Hedley M, 2013. Effect of biochar on soil physical properties in two contrasting soils: An Alfisol and an Andisol. Geoderma 209-210:188-197.

İlay R, Erarslan G, Kavdır Y, 2019. Co-composting of olive pomace and fish wastes and use in soil improvement. Anadolu Tarim Bilimleri Dergisi 34:201-209.

İlay R, Kavdır Y, 2018. Impact of land cover types on soil aggregate stability and erodibility. Environmental Monitoring and Assessment 525.

Kavdır Y, Killi D, 2008. Influence of olive oil solid waste applications on soil pH, electrical conductivity, soil nitrogen transformations, carbon content and aggregate stability. Bioresource Technology 99:2326-2332.

Kavdır Y, Ekinci H, Yüksel O, Mermut AR, 2005. Soil aggregate stability and 13C CP/MAS-NMR assessment of organic matter in soils influenced by forest wildfires in Canakkale, Turkey. Geoderma 129:219-229.

Kemper WD, Rosenau RC, 1986. Aggregate stability and size distribution. Methods of Soil Analysis: Part 1 Physical and Mineralogical Methods 5:425-442.

Lado M, Paz A, Ben-Hur M, 2004. Organic Matter and Aggregate-Size Interactions in Saturated Hydraulic Conductivity. Soil Science Society of America Journal 68:234-242.

Li Y, Fang F, Wei J, et al, 2019. Humic Acid Fertilizer Improved Soil Properties and Soil Microbial Diversity of Continuous Cropping Peanut: A Three-Year Experiment. Scientific Reports 9:1-9.

Marinari S, Masciandaro G, Ceccanti B, Grego S, 2000. Influence of organic and mineral fertilisers on soil biological and physical properties. Bioresource Technology 72:9-17.

Nemes A, Rawls WJ, Pachepsky YA, 2005. Influence of Organic Matter on the Estimation of Saturated Hydraulic Conductivity. Soil Science Society of America Journal 69:1330-1337.

Obi ME, Ebo PO, 1995. The effects of organic and inorganic amendments on soil physical properties and maize production in a severely degraded sandy soil in southern Nigeria. Bioresource Technology 51:117-123.

Pekcan T, Esetlili BÇ, Turan HS, Aydoğdu E, 2018. Leonardit kökenli organik materyallerin bazı fiziksel ve kimyasal özelliklerinin belirlenmesi. Uludağ Üniversitesi Ziraat Fakültesi Dergisi 32(1): 31-41. 
Pritchett K, Kennedy AC, Cogger CG, 2011. Management effects on soil quality in organic vegetable systems in western Washington. Soil Science Society of America Journal 75:605-615.

Rasool R, Kukal SS, Hira GS, 2008. Soil organic carbon and physical properties as affected by long-term application of FYM and inorganic fertilizers in maize-wheat system. Soil and Tillage Research 101:31-36.

Schlichting E, Blume HP, 1966. Bodenkundliches Praktikum: Verlag Paul Parey, Berlin.

Schumacher BA, 2002. Methods for the determination of total organic carbon (TOC) in soils and sediments.

Smith HW, Weldon MD, 1941. A Comparison of Some Methods for the Determination of Soil Organic Matter 1. Soil Science Society of America Journal 5:177-182.

Toková L, Igaz D, Horák J, Aydin E, 2020. Effect of Biochar Application and Re-Application on Soil Bulk Density, Porosity, Saturated Hydraulic Conductivity, Water Content and Soil Water Availability in a Silty Loam Haplic Luvisol. Agronomy 10 (7):1005.

Whitbread AM, Blair GJ, Lefroy RDB, 2000. Managing legume leys, residues and fertilisers to enhance the sustainability of wheat cropping systems in Australia: 2. Soil physical fertility and carbon. Soil and Tillage Research 54:77-89. 